\title{
Obligatory Share and Entitled Entities: An Obligatory Share during Testamentary Inheritance
}

\author{
Ekaterine Nandoshvili (PhD Student) \\ Grigol Robakidze University, Tbilisi, Georgia
}

Doi:10.19044/esj.2021.v17n6p1

Submitted: 09 October 2020

Accepted: 14 January 2021

Published: 28 February 2021

\author{
Copyright 2021 Author(s) \\ Under Creative Commons BY-NC-ND \\ 4.0 OPEN ACCESS
}

Cite As:

Nandoshvili E. (2021). Obligatory Share and Entitled Entities: An Obligatory Share during Testamentary Inheritance. European Scientific Journal, ESJ, 17(6), 1.

https://doi.org/10.19044/esj.2021.v17n6p1

\section{Abstract}

This paper focuses on the results of the research of normative acts and practices regulating the institute of mandatory shares and entities with the right to the mandatory shares. Formation of the correct view on this issue is a precondition for the redistribution of property in accordance with the law of inherited property, both in court and in notarial practices. In turn, the proper redistribution of the inherited property is directly related to the protection of property and inheritance rights. This is why the studied issue does not lose its urgency. The aim of the paper is to correctly define the essence of the mandatory share, as well as the subjects entitled to the mandatory share, to identify the shortcomings in this issue, and to develop recommendations for their perfection. The comparative-legal, logical, and systematic analysis of norms were used to achieve this goal. Problems were analyzed using the examples of Georgian, German, and Swiss law. In defining the mandatory share and the subjects entitled to it, both common features and essential differences were revealed between the named models, This, however, makes it possible to define a more effective model - a number of advantages of the Georgian model were identified - which is reflected in the mechanism of effective exercise of the right to mandatory share without a court. In addition, the study found that the testator's grandchildren are not eligible entities to receive a mandatory share if their parent died before the testator. The legal norms of inheritance are interpreted in relation to the Constitution. On this basis, the shortcomings of a number of norms for both the Civil Code of Georgia and the Law of Georgia "On Entrepreneurs" and even non- 
compliance with the Constitution are identified. This is why it is necessary to improve them and create the stable guarantees for the right of property and inheritance.

Keywords: Mandatory share, inheritance, will, first devisee heir

\section{Introduction}

Compared to the Civil Code of the Soviet Socialist Republic of Georgia (1964 edition), the circle of entities which can acquire the right to a mandatory share was regulated significantly and differently. It is also important to note that despite the influence of German law, which was clearly outlined in the development of the applicable Civil Code, a lot of differences remained on the issue of the regulation of the mandatory share. The reform of Georgian private law did not end with the adoption of the applicable Civil Code. It is now on the way to perfection, which should lead to the strengthening of effective mechanisms for the rights of subjects of law. First and foremost, rights of property and inheritance. Therefore, this paper focuses on using a systemic and comparative method for analyzing the effectiveness of norms, which determine the origination of the right to demand the mandatory share, as well as the circle of entities with the right to the obligatory share. Such an analysis will apply to both the provisions of the Civil Code of Georgia and the Law of Georgia "On Entrepreneurs" and court practice. The purpose of the analysis of practice and these norms is to identify shortcomings in both legislation and practice, and to develop proposals for improving legal norms and practices. Since many institutions in the Civil Code of Georgia are accepted from German law, this study aims to determine the similarities or differences between the Georgian and German models, which allows us to see the advantages of this or that model.

In addition, the goal of the study aims to research the inconsistency of the applicable legislative acts with the Constitution of Georgia in the part where these acts contradict the right to property and inheritance guaranteed by the Constitution of Georgia.

During research, logical and systematic norms analysis was used, as well as comparative-legal methods. Through these methods, it is possible to determine the validity of the norms of Georgian law or to have a better understanding of their content, Identify gaps in legislative provisions in notarial and case law, and also develop proposals and recommendations for improving norms and practices as described below.

In the course of writing this article, Georgian Legal Literature and Georgian Court and Notarial practice was mainly selected. It is a fact that the 
lack of professional literature is a serious problem in Georgian heritage law ${ }^{1}$. Thus, we are not spoiled by the broad and uniform Court practice regarding the research topic either. All this poses a threat to the formation of heterogeneous and inconsistent Court or Notarial practice, which overshadows inheritance law as one of the oldest and most important fields of law for civil turnover.

\section{Obligatory Share on the example of Georgian and German Law a) Georgian Law}

There is an opinion that the "Institute of Obligatory Share can be considered as a specific type of inheritance. It does not explicitly belong to inheritance by either the lawful or the will. Nevertheless, both kinds of inheritance elements can be found in it. Inheritance of a mandatory share is not a variety because it is entirely due to the existence of a will. It differs from inheritance by will in that it implies the restriction of the Will and the definition of those persons by law, who have the right to receive an Obligatory Share" (Shengelia \& Shengelia, 2019, p. 370). In accordance with a similar definition, "Heirdom of an Obligatory Share is not a pure form of heredity by law, as long as its issue won't arise unless a will is drawn up. Thus, it is related to the Will, although it is carried out against it" (Akhvlediani, 2007, p.45). According to a similar German notion, "Free decision on the division of the estate - or freedom of drawing up a will (Testierfreiheit) - is restricted by an Obligatory Share" (Nitschmann, Pflichtteilsrecht einfach erklärt - das Pflichtteilsrecht im Überblick, 2018).

Using the Code of Civil Law of the Georgian SSR before the entry into force of the current Civil Code, the amount of the subjects entitled to the Obligatory Share and the amount of the share itself was defined differently. According to the article 547 of the current Code of Civil Law of the Georgian SSR edited by 1964, disabled adult children, disabled spouse, parents and other legal heirs on the survival or satisfaction of the testator were considered to be entitled to the Obligatory Share. Hence, the minor child of the testator had the same right. Therefore, the incapacity in determining the circle of subjects entitled to the Obligatory Share "had a definitive meaning" (Shengelia \& Shengelia, 2011, p.84). The obligatory share should not have been less than two-thirds of the property that the person would have inherited by law at that time. Thus, modern Georgian legislation regulates differently the circle of subjects entitled to the Obligatory Share and the amount of a mandatory share as well. In the Georgian legal literature, there is conflicting notions in regards to this. Particularly, according to one of them, only disabled

${ }^{1}$ ex.: There is no decision of Georgian Supreme Court regarding Article GL 1379; see: http://prg.supremecourt.ge/CaseCivilResult.aspx (last seen 19.02.2020) 
heirs should have the right to receive the Obligatory Share, and the Obligatory Share should form one of the main sources of their existence (Chikvashvili, 1999, p. 461).

According to the second opinion, the above-mentioned position is "the Soviet in its content and is essentially contrary to the principles of market relations. It does not emerge from the interests of family members, too." In case the institution of Obligatory Share was mostly considered as a means of eliminating the money of the relatives of the heir, this task was selected due to the new circumstance. A disabled child, parent or spouse has no advantage over a disabled person in the process of earning a living. In addition, the new approach of the law to the Obligatory Share is an expression of the actual fulfillment of moral obligations to a family member (Shengelia \& Shengelia, 2011, pp.84-85).

Consequently, it should be noted that the second view deserves more support. In addition, it can be noted that the unjustified restriction of the circle of subjects entitled to the Obligatory Share with reference to various circumstances (in this case disability) will cause the violation of the constitutional rights of first-degree heirs. According to Article 19 of the Constitution of Georgia, "the right to property and heritage is recognized and guaranteed." Thus, the Obligatory Share is an Inheritance. The definition of the circle of entitled persons to it should depend on the status of the subject (child, parent, spouse, etc.) and not on legal facts (disability, etc.). On the other hand, expanding the circle of obligatory heirs is also inadmissible, as this may decrease the essence of the institution of the will itself. However, it is noteworthy that the fact about the incapacity for work is not neglected in Georgian legislation in terms of heritage.

However, this factor is the basis for receiving alimony (alimony and not obligatory share). Specifically, Article 1338 of the Civil Code decreed that disabled persons who were the heirs of the heir and could not save themselves independently, unless they are indicated in the will, have the right to claim alimony from the inheritance.

Based on the above, it can be said that from the current legislation, the issue of the volume of Obligatory Share is not correctly defined. Also, the circle of authorized persons for the mentioned share is properly regulated.

\section{b) German Law}

A similar institute of the Obligatory Share is known to the legislation of not one of the countries. They may have different names, different compositions of persons entitled to this right, and different amounts of shares. This institution, as a rule, envisages the guaranteed provision of the closest relatives of the heir by receiving a certain share from the inheritance (Shengelia \& Shengelia, 2019, p. 370). 
"There is the same model of Obligatory Share... in Germany" (Shengelia \& Shengelia, 2019, pp. 370-371).

Furthermore, there is an opinion that "Section 5 of the German Civil Code, which deals with the issues of Obligatory Share, is similar to the norms of Georgian hereditary law" (Shengelia \& Shengelia, 2019, pp. 370-371).

However, this is a debatable point because, like Georgian law, German law was established for the obligatory share of half of the heritage share accepted by law. Nevertheless, unlike Georgian law, German law, for example, gives the right of obligatory share not only to the children of the testator, but also, in general, to the descendants of the heir, or to the grandchildren, their children, and so on. This is directly stated in Article $\mathbf{2 3 0 3}$ of the German Civil Code (BGB) about the "descendants" of the heir (generally) and not (only) the "children" (BGB - German Civil Code, 2019, p. 543). Besides, German law gives the right to claim the Obligatory Share, not only to the spouse, but also to the registered partner (Lebenspartner) (German Law on a Registered Life Guide (Partner)).

In the matter of compulsory share, a significant difference is revealed between the legislative provisions of German and Georgian inheritance law based on the terms and conditions of the origin of the right to compulsory share. The obligatory share in German law is referred to as the right to a monetary claim in the event of a dispute, which gives rise to a relationship of obligation with the testator heir. The demand arises from the time of opening the estate. Unlike Georgian law, a person authorized to receive a compulsory share in German law does not always have the right to claim an obligatory share. If such person receives a share of the estate equal to or greater than the required share, he loses the share requirement (Jauernig, 2003). The term "Obligatory Share" is not recognized by German law. For instance, in Germany, "The Right to claim a Mandatory Share" is exercised by submitting such a claim to the testator's heir.

Thus, under German law, a person entitled to an Obligatory Share must make that claim by filing a claim in court (Jauernig, 2003). In addition, German law does not always give birth to a right to a compulsory share. Even when that right arises, its exercise is complicated by the necessity of court proceedings.

In the existence of such a complex mechanism, the role of the notary as a person in charge of an indisputable fact / indisputable right is neglected. The authorized person depends on the will of the testator and if the latter does not transfer the obligatory share, he is deprived of the opportunity to apply to the notary for the issuance of a certificate of inheritance. Unlike German, the rules under Georgian law are more flexible and valid, according to which a holder of such a right may acquire a right to a compulsory share on the basis of a notarized inheritance certificate, rather than a testamentary heir to the 
testamentary estate. In general, the latter may need to establish or extend the fact of acceptance of the estate or the period of receipt of the estate by the court, etc. Under German law, a binding relationship arises between the holder of that right and the testator in connection with the exercise of the right to a compulsory share. Consequently, it turns out that a certificate of inheritance can never be issued by a notary public, and the exercise of the right by the court will delay the process of obtaining the right.

In addition to the above, a person entitled to a compulsory share in Germany can claim a compulsory share within three years (Kropholler, 2014, p.95). The analysis of Georgian legislation shows that the right to property, as an absolute right, cannot be the subject of obsolescence. The point is that if a person receives a compulsory share, that share becomes his property by virtue of the law.

It is also interesting to note that the Swiss Civil Code (ZGB) contains similar provisions at least for those of the German Civil Code norms in relation to the obligatory shares and entitlements. For instance, according to Article 457 (1) of the Swiss Criminal Code, "the closest heirs of the heir are his descendants" (Switzerland Civil Code, 2017, p. 135).

\section{Problems}

In this study, the regulating norms of the obligatory share are discussed in systemic connection with the norms of the general part of the inheritance law and the norms regulating the heritage by law. This is done so as to properly analyze the problems related to the obligatory share. The need for a systematic research is due to the strict definition of the boundaries between the named norms, the necessity, the violation of which in practice will cause the incorrect qualification of disputes related to the obligatory share. Therefore, incorrect definition of the subjects is entitled to the obligatory share, which in turn will undoubtedly provoke the violation of the rights of the testator heir (including the rights of the persons entitled to the obligatory share). Judicial practice on this issue is heterogeneous. The reason for this may be the fact that the regulation of inheritance relations is characterized by the equal usage of the norms of the general part (A general part of the 6th book of Civil Code) of the inheritance law to both types of inheritance - inheritance by law and will. Moreover, it is possible to apply not only the norms of the general part, but also some norms regulating the heritage by law in the case of testamentary inheritance. Based on the general part, general norms and, in general, the goodness of the general part, in the legislative technique, the literature published after the enactment of the current Civil Code of Georgia focused specifically on Professor Lado Chanturia who stated: "The Civil Code recognizes the second type of the general part, which is reinforced in separate books of the Code and... forms the basis for regulating the relationships 
provided by this book. ... The general part of this category includes ... general provisions of inheritance law" (Chanturia, 1997, pp. 85-86). According to the scientist, "the greatest advantage of the general part is that it provides the foundation on which the whole legal body of a given law or field of law is built" (Chanturia, 1997, p.84).

Courts are likely to make a mistake especially when they have to resolve disputes on the basis of special norms. In this regard, it should be noted that the norms governing inheritance and compulsory inheritance are reflected in two different chapters of the Civil Code. The norms given in both chapters are special norms, although this factor does not exclude the possibility that these norms complemented each other. For example, according to Article 1374 of the Civil Code, in determining the obligatory share of each heir, all legal heirs who would have been invited to receive the inheritance should have been taken into account, in case of absence of will. The circle of heirs by law is given in Article 1336 of the Civil Code. Consequently, the use of these two norms in combination - without explanation - made it impossible to decide the issue of volume of obligatory share.

Various disputes are used arising between the subjects of inheritance law about the scope and content of their rights. In view of the above and based on the analysis of the Court law, it is possible to formulate an approach as to which reasoning in the case law should be shared and which should not. In such cases, due to hereditary relations, the resolution of the legal issue (the issue of ownership) is beyond the scope of notarial jurisdiction. This is because the notary is authorized to fulfill the notarial act only in case of confirmation of the inalienable rights (Sukhitashvili, 2012), i.e., in the case where there is no dispute between the interested parties about the material right.

The point is that the correct interpretation of this or that norm of the Civil Code, which is given in the Court law, will promote to improve not only the Court law, but also the perfection of notary practice. On the other hand, if the court resolves the disputed issue, or explains the content of the norm in the decision rendered as a result of the dispute, such an explanation can be used in notary practice as well. In undoubted case, the norm is carried out by a notary at which the Court practice. It is established for the correct understanding of the content of the applicable norms and has a defining importance, which also contributes to the formation of the correct notarial practice. For its part, the establishment of correct case law should be facilitated by scientific analysis of norms.

Logical and systematic analysis of norms as well as comparative-legal methods was used in the research. Using these methods, it is possible to identify gaps in the mechanisms implemented in the notarial and judicial practice of legislation, to develop proposals for the improvement of norms and practices. 
As a result of the problem study, it became apparent that there are different approaches to the subjects entitled to the obligatory share in case law. There should be no problem on this issue, since, by the law, it clearly defined the subjects entitled to the obligatory share. These include spouse, child, parent, or first-degree heirs of the heir. However, the case became complicated when at the time of the opening of the estate, the son of the heir who was supposed to be his heir is no longer alive; instead the son of the deceased son of the heir is alive. According to Article $\mathbf{1 3 3 6}$ of the Civil Code of Georgia, grandchildren are considered as heirs only under certain conditions. Nevertheless, there is discourse of their rights to become heirs based on the law in the presence of the named conditions. This occurs when at the time of the opening of the estate, his parent was no longer alive-who would have been the lawful heir.

In accordance with Article $\mathbf{1 3 7 1}$ of the Civil Code, the right to claim the obligatory share arises from the date of opening the estate. This right is inherited. It is interesting, based on the analysis of the given norms, when a person (grandchild) receives the obligatory share during the opening of the estate, especially when his parent, who is included in the circle of first-degree heirs, is no longer alive. Both of these norms are placed in different chapters and, as we have said, they are special norms. I have also pointed out that the case-law, in some cases, considers it permissible to use special norms as complementary norms. Thus, it is interesting to note that it has a complementary character in Article 1336 and Article 1371 of the Civil Code in the context of defining the right of subjects when the case concerns the right of the grandchildren on the obligatory share. We have to answer this question negatively. As for the Court law, there is no unambiguous answer to this question in practice. The practice of the Supreme Court is interesting in this regard because it is through the acts of the mentioned court that it is necessary to promote the establishment of a uniform practice. In particular, in the earlier case, as set out in the judgment of 19 December 2002 (Case №3k-1000-02), the Court of Cassation considered a grandchild to be a person entitled to receive the Obligatory Share if his parent (heir) was not alive at the time of the estate opening. According to the court, under Article $\mathbf{1 3 7 1}$ of the Civil Code, if the testator's son had been alive, even though there is a will, it would still have been possessed by the Obligatory Share. The Court also applied Article 1336 and concluded that due to the earlier death of the testator's son, his share of the estate passed to his son, the testator's grandson. According to Article 1372 of the same Code, the right to claim the Obligatory Share arises from the moment of opening the estate. Such a claim is inherited. ${ }^{2}$

${ }^{2}$ Like this explanation of the Court, in notarial practice there are often cases when, against the requirements of the law, notaries also consider that the Obligatory Share belongs to the grandson and issue an inheritance certificate to them. 
The same court ruled against the above decision in its judgment of $\mathbf{6}$ June 2013 in the case (№as-1577-1480-2012). The court clarified that if the death of the testator precedes the death of the person entitled to receive the Obligatory Share, the power to receive the compulsory share cannot be inherited by the heirs.

The mentioned definition should be considered correct. It is based on a proper understanding of the governing norms of the Obligatory Share. In the above case, the Court of Cassation did not properly share the appellate court's legal assessment that by introducing the institution of the Obligatory Share, the legislature restricted the freedom of the testator. The interests of the heirs, including the grandson, were taken into account under the first-degree law, if at the time of the opening of the estate his parent, who would be the lawful heir, was no longer alive.

In the Court of Cassation's view, such a finding by the Court of Appeal is neither literally with the law nor with its logical and systematic interpretation.

It should be noted that for a correct interpretation of Article 1371 of the Civil Code, it is necessary to analyze it in a systematic connection with Articles 1306 and 1336-1343 of the Civil Code. Nevertheless, the logical interpretation of Article 1371 must, above all, be facilitated by the consideration of a supposedly general institution of legal capacity. Most especially, Articles 1336-1343 of the Civil Code do not contain any reservation on the Obligatory Share. Also, Article 1371 does not specify the subjects entitled to the obligatory share in general and from the circle of heirs in particular, but rather, such persons are stated specifically and independently without any reference to Article 1336. Such an explanation of Article 1371 of the Civil Code clearly shows that the grandchildren of the heir are not mentioned among the subjects entitled to the Obligatory Share.

The application of Article $\mathbf{1 3 3 6}$ of the Civil Code to the benefit of the grandchildren in the aspect of recognition of the right to the Obligatory Share is also excluded by the provision of Part $\mathbf{2}$ of Article 1306, which involves the implementation of the inheritance by law. Therefore, the application of the norms regulating the heirs at law is possibly considered only in the absence of a Will or in a condition when the Will includes part of the estate, or the Will is declared void entirely or partly. Systematic analysis of the above norms reveals that in order to determine the right to the Obligatory Share and the subjects with this right, it is inadmissible to use the norms of inheritance by law. It is true that Article $\mathbf{1 3 0 6}$ does not contain a legal basis ${ }^{3}$ (Todua \&

\footnotetext{
${ }^{3}$ Based on the legal basis of the claim, the rule of law gives the creditor the right to demand the debtor to carry out the action, see: Todua, M. / Kurdadze, Sh. - Peculiarities of decisionmaking in a separate category of Civil Case 2005, p. 166.
} 
Kurdadze, 2005, p. 166) for the claim and is a general norm in this attitude. Thus, envisaged by its systematic connection with Article $\mathbf{1 3 7 1}$ of the Civil Code, it is possible to give a correct and logical explanation of the content of Article $\mathbf{1 3 7 1}$ of the Civil Code.

The content of Article $\mathbf{1 3 7 2}$ of the Civil Code must be taken into account for the definition of the rights of grandchildren on the Obligatory Share and for the correct definitions of Article 1371. Attention should be paid to the words: "The right to claim the obligatory share arises from the moment of the estate opening". The origin of the right to claim is related to a legal capacity. Our goal is not to research the mentioned Institution ${ }^{4}$. We only mention that legal capacity has the possibility of being a subject of law. It is the ability of a person to have civil rights and duties (Article $\mathbf{1 1}$ of the Civil Code), which is terminated upon the death of that person. Consequently, if the testator's child, as his first-degree heir, entitled to the Obligatory Share dies before the testator, he does not have the right to claim either. Therefore, a nonexistent right (including to the Obligatory Share) cannot be inherited. It is directly derived from the provision of Article $\mathbf{1 3 7 2}$ of the Civil Code, which the existence of several legal facts is necessary for the origin of the inheritance relationship related to the obligatory share. These legal facts are the death of the heir or the declaration of death in a prescribed manner, which causes the estate opening; the presence of the first-degree heirs of the testator, who are entitled to the Obligatory Share to be alive; and the reception of the Obligatory Share by the latter as an inheritance. Accordingly, the right to receive an Obligatory Share can be used only by the heir entitled to receive an Obligatory Share who was alive at the time of the testator's death. It logically follows that if such an heir dies earlier than the testator, the right to receive an Obligatory Share cannot arise.

It is true that the second sentence of Article $\mathbf{1 3 7 2}$ of the Civil Code provides for the transmission of the right to claim an Obligatory Share. However, according to the same norm, transmission is permissible if the heir entitled to receiving the obligatory share died after opening the estate and he could not receive the obligatory share ${ }^{5}$. Therefore, in the presence of a special norm, it is impossible to use the representative transmission envisaged by Article $\mathbf{1 4 3 0}$ of the Civil Code.

\footnotetext{
${ }^{4}$ The institute of legal capacity has been studied in details in the Georgian legal literature, see: Chanturia, L. - General Part of Civil Law, Kobakhidze, A. - Civil Law, General Part I, Tbilisi 2001; Moniava, T. (P.) - Introduction to the General Part of Civil Law, Tbilisi 2013.

${ }^{5}$ In our opinion, the formulation of Article 1430 of the Civil Code requires a change. The words "before receiving the inheritance", as well as the words "right to receive a share" should be suitably replaced with the words: "before the inheritance is registered", "the inheritance is transferred", since, ...
} 
Article 1371 of the Civil Code of Georgia aims to determine the circle of subjects entitled to receive an Obligatory Share, "other members of the heir's family do not benefit with a similar right" (Shengelia \& Shengelia, 2011, pp. 83). The unworthy heir does not have the right to receive an Obligatory Share, since he has been deprived of the right to inherit.

The acquisition of an Obligatory Share is related to another issue, namely, the norms governing the testamentary inheritance are contradictory in the matter of the free will or restriction of the testator's will. In regards to the research issue according to the law, the testator must be an adult and a fullfledged person. Therefore, even an adult person with disabilities cannot compose a will because such person's will is expressed with the consent of the guardian. When making a will, no one (including the caregiver) can influence the will of the testator. We mentioned this example because in this way, the legislator, in our opinion, emphasized the unconditionality of the testator's will. On the other hand, Article 1371 restricted the will of the testator by granting an Obligatory Share to his first-degree heirs, regardless of his will or the content of the will.

As mentioned above, it is interesting to ask whether the testator can avoid the Obligatory Share of the testator in favor of the heirs by the firstdegree heirs. In this regard, the regulation reflected in the Civil Code is not so perfect. It is clear that the recognition of an unworthy heir also deprives the first-degree heir of the right to the Obligatory Share, but it is quite possible that there is no basis for the recognition of a person as an unworthy heir. Subsequently, the heir does not want to attribute anything even to the firstdegree heir in the form of an Obligatory Share.

In connection with the above, it is noteworthy that the provision of Article 1354 of the Civil Code allows for the deprivation of the right to inherit by direct reference to the will. It is interesting that if the testator benefits from the provision of this norm, the first-degree heirs will still have the right to an Obligatory Share under Article $\mathbf{1 3 7 1}$ of the Civil Code, which gives the possibility of obtaining an Obligatory Share regardless of the content of the will. In our opinion, this question requires a negative response. We consider that the words mentioned in Article $\mathbf{1 3 7 1}$ of the Civil Code "... of the will", "... regardless of the content of the will", "an Obligatory Share belongs to ..." should not be widely understood. The content of the will implies the freedom to choose the heirs of the will alone, and this freedom is restricted by the named norm. As explained in the commentary to Article $\mathbf{1 3 5 4}$ of the Civil Code, in the case of a direct indication in the will that the heir is deprived of the inheritance by a certain law, the heir by law will in no case get a share from the estate (Akhvlediani, 2000, p.410).

However, we are faced with another important problem, of which the necessity of analysis is conditioned by the complex nature of hereditary legal 
relations. The matter indicates that the mentioned relations are regulated not only by the Civil Code, but also by the Law of Georgia "on Entrepreneurs". Therefore, the provisions reflected in it apply equally to both types of inheritance. According to the first paragraph of Article 33 of the named law, upon the death of a partner of a Joint Liability Company and several liability company (hereinafter referred to as the "JLC"), each heir can become a partner of the company if this is envisaged for in the charter of the company or if all partners agree. According to paragraph $\mathbf{2}$ of the same article, the charter of the company may stipulate that one or more heirs can become a partner. In such situation, the person entering the society as a partner is obliged to pay appropriate compensation to other heirs. The Charter of the Company may not provide for the obligation of compensation.

In accordance with Article $\mathbf{4 3}$ of the Law of Georgia "On Entrepreneurs", a Limited Company (hereinafter referred to as "LC") of Limited Partner or alienation or inheritance of a Limited Share may occur without the consent of other partners, unless the charter provides otherwise. Also, a notarized written agreement is required when the share is conceded. ${ }^{6}$

According to Article $\mathbf{6 2}$ of the Law of Georgia "On Entrepreneurs", the charter may stipulate that a member of a cooperative (i.e., a member and not the heir of a deceased member) will become its successor. The extension of membership by the charter may depend on the personal factors of the successor. In case of inheritance by several heirs, the membership will be terminated if it is not transferred to one of the heirs within the timeframe established by the charter.

Accordingly, the right of inheritance can be limited both in partnership-type entrepreneurial societies (JLC, LC) and in capital-type entrepreneurial societies (cooperatives). ${ }^{7}$ As it is well known, entrepreneurial and generally private law in Georgia was developed under the influence of German law, and it seems that this factor has led to the existence of such provisions. In the German literature on the research of the problems of entrepreneurial law, such reservations are justified by the personal nature of the company share. This is why "a share of the society by inheritance is transferred only if the contract of the society (meaning the charter - the emphasis is mine - E. N.) contains a reservation of legal succession". ${ }^{8}$

\footnotetext{
${ }^{6}$ In this norm, the word "written" is superfluous and removable as a notarized contract which already implies its existence in writing.

${ }^{7}$ For details on Partnership and Capital Type Society, see: Chanturia, L. / Ninidze, T. Commentary on the Law "On Entrepreneurs", Tbilisi 2002; Kokrashvili, K. "Entrepreneurial Law" Tbilisi 2010.

${ }^{8}$ This opinion is mentioned in relation to the German Open Trade Society (which in Georgian law is a limited liability company, LLC) in the book: Carsten Schefer Law of Societies, $5^{\text {th }}$ edition, published by the Notary Chamber of Georgia, 2018, p. 144.
} 
We consider that since such disciplines apply to both types of inheritance, they limit and sometimes provoke the loss of the right to inherit (including the property provided by the will and also the obligatory share of the inheritance). However, this is unjustified and contradicts the provision of the Constitution of Georgia, according to which the right of inheritance, together with property, is recognized and secured. They also restrict the will of the heir himself, unilaterally, to dispose of his property freely at the time of death. It should be considered that the Law "On Entrepreneurs" was adopted on October 28, 1994 and entered into force on March 1, 1995. Nevertheless, the Constitution of Georgia was rendered on August 24, 1995. The Constitution guarantees the right of inheritance without any compact or exceptions.

In order to determine the contradiction with the Constitution, it is necessary to make a detailed analysis of the above-mentioned norms of the Law "On Entrepreneurs" (hereinafter abbreviated law). In particular, Article $\mathbf{3 3}$ of the Law generally does not preclude inheritance. However, because it excludes partnership on the acquired share based on the inheritance received, the fulfilment of the right turns to zero in the field of entrepreneurship. In addition, the provision of the mentioned norm does not provide for a legal result at all, especially the right to compensation in the event that the heir to the inherited estate (regardless of the share) fails to become a partner. The right to compensation is provided only in Article $\mathbf{3 2}$ and in the case when the partner leaves the society, which is a different case from the death of the partner. The heir of the inherited property becomes the owner, but not the partner, while Article 32 deals with the partner (departure of the partner). The compensation provided for in paragraph $\mathbf{2}$ of Article $\mathbf{3 3}$ of the Law also refers to the obligation of the partner. The last sentence of paragraph 2 Article 33 of the Law is vague: "The charter of a company may not envisage the obligation of compensation". It causes an ambiguity as to who is the addressee of this rule. If the addressee of the norm is the heir, then why does the statute restrict the right of someone to voluntarily pay compensation to another heir? If the addressee of the norm is an entrepreneurial company, then why should the heir not be compensated?

As for Article 43 of the Law on Entrepreneurs, in certain cases, in particular, when the restriction is provided for in the charter, it excludes the inheritance of a partner (limited partner) (an Obligatory Share is also considered). The named norm is dispositional and the transfer of shares by inheritance depends on the consent of other partners. Therefore, without their consent, the heir will not receive a share. Therefore, he will not be able to become a partner through succession, and there is nothing mentioned in the law on compensation. 
According to paragraph 4 Article $\mathbf{6 2}$ of the named law, the charter may provide for the exclusion of legal heirs (the heirs provided for in Article $\mathbf{1 3 3 6}$ of the Civil Code - emphasis mine - E. N.) in the cooperative as well. According to the norm, the charter may stipulate that in case of the death of a member of the cooperative, the member of the cooperative will become his successor. Of course, it means not inheriting the whole estate in general, but inheriting the membership and the membership of a member. Here, along with everything else, the legislator has allowed serious inaccuracies in terms of legal technique. According to the general rule established by the first sentence of paragraph 4 Article $\mathbf{6 2}$ of the Law of Georgia on Entrepreneurs, upon the death of a member of a cooperative, membership is transferred to his heirs. The inaccuracy is that according to Article $\mathbf{1 3 2 8}$ of the Civil Code, the inherited property consists of its own assets and liabilities during the life of the heir, i.e., the combination of property rights and obligations. Therefore, membership in the estate does not include itself, but it is a set of rights and obligations (assets and liabilities) in consequence of membership in the cooperative.

\section{Conclusion}

Due to the above-mentioned discussion, the following conclusions were drawn from this study: Comparison of Georgian law with the institution of mandatory share in German law reveals the superiority of Georgian law in regulating the mandatory share. Georgian law allows obtaining a compulsory share without a court, in particular, through a notary. An entity entitled to an Obligatory Share in this matter is not dependent on the will of the testator. Hence, this is the case in German law, which is why German law provokes litigation. Under such a rule, the court is overloaded, which is not necessary. It is true that the judiciary is a universal body for the protection of rights, but it is not the only body for the protection of rights. Whether a person acquires the right to a compulsory share without a court should not depend on the actions of the testator heir. The circle of persons entitled to the obligatory share cannot be increased at the expense of the norms regulating the inheritance by law, as some courts have learnt. Nevertheless, this issue is properly resolved in the practice of the Supreme Court. This, however, is the reason it is inadmissible to invite grandchildren to receive an Obligatory Share, especially when their parents, at the time of the estate opening, are no longer alive. The issue of mandatory share volume requires a new arrangement. In particular, as research shows, under the law of some countries, the spouse is not included in the circle of heirs at all. Georgian law grants, on two grounds, the spouse the right to own (share) the property acquired during the period of cohabitation by co-ownership - and by inheritance mode. The spouse is also a person entitled to an Obligatory Share. Thus, the amount of the obligatory share 
should be less for a spouse, who is also a co-owner of the property. Consequently, the research revealed the imperfection of the inheritance-legal norms provided by the Law "On Entrepreneurs" and in some cases a contradiction with the Constitution.

\section{References:}

1. Akhvlediani, Z. (1998). Some Issues of Inheritance according to the New Civil Code of Georgia, Journal "Review of Georgian Law", Tbilisi.

2. Akhvlediani, Z. (2007). Law of Inheritance, Third Edition, Publishing House "Bona Causa", Tbilisi.

3. BGB (2019). German Civil Code, Second Edited Edition, Tbilisi.

4. Chanturia, L. (1997). General Part of Civil Law.

5. Chanturia, L. (1997). Introduction to the General Part of the Civil Part of Georgia, Publishing House "Samartali", Tbilisi.

6. Chanturia, L. \& Ninidze, T. (2002). Commentary on the Law on Entrepreneurs, Tbilisi.

7. Chikvashvili, S. (1999). Law of Family and Inheritance, Tbilisi.

8. Commentary on the Civil Code of Georgia (2000). Book 5, Collective of Authors, Tbilisi.

9. Dzneladze, N. (2000). Problems of the Institute of Compulsory Share in Inheritance Law, Journal "Samartali", №6-7.

10. Hertel, C. (2009). Rechtskreise im Überblick, Notarius International 12.

11. Jauernig, O. (2003). BGB, Bürgerliches Gesetzbuch Kommentar, 10 Auflage, Verlag C.H. Beck, München.

12. Kropholler, J. (2014). German Civil Code - Study Commentary, the $13^{\text {th }}$ revised edition, Tbilisi.

13. Kobakhidze, A. (2001). Civil Law, General Part I, Tbilisi.

14. Kokrashvili, K. (2010). "Entrepreneurial Law" Tbilisi.

15. Moniava, T.P. (2013). Introduction to the General Part of Civil Law, Tbilisi.

16. Pepin, Y. \& Lachance, M. (2003). Länderbericht Québec,Notarius International 3-4.

17. Shengelia, R. \& Shengelia, E. (2011). Law of Family and Inheritance, Third Edition, Publishing House "Meridiani", Tbilisi.

18. Shengelia, R. \& Shengelia, E. (2019). Law of Family and Inheritance, Third Edition, Publishing House "Meridiani", Tbilisi.

19. Sukhitashvili, D. (2012). Notary Law, Tbilisi.

20. Swiss Civil Code (2018). January 1, 2017, Tbilisi.

21. Todua, M. \& Kurdadze, SH. (2005). Peculiarities of decision-making in a separate category of civil cases. 